\title{
RIGHTS OF THE PUTATIVE AND MERETRICIOUS SPOUSE IN CALIFORNIA
}

This comment will present a comparative discussion of the rights of putative and meretricious spouses ${ }^{1}$ in California, together with an analysis of the principles upon which these rights depend. Catagorizing plaintiff as either putative or meretricious and then discussing the relative rights of each affords a convenient method of approach. Therefore, the basic characteristics that define plaintiff as putative and the rights accorded upon such qualification will be discussed first. Then, a similar treatment of the meretricious spouse will follow.

\section{I}

\section{THE PUTATIVE SPOUSE}

\section{A. Qualification}

A putative marriage is one in which at least one of the parties has a good faith belief that the relationship existing between them is a valid marriage. ${ }^{2}$ Only a party having such a belief is a putative spouse. ${ }^{3}$ No marriage ceremony is necessary. Even a good faith belief that a common law marriage was valid is sufficient to make the believer a putative spouse.

A person incapable of contracting a valid marriage is not thereby barred from becoming a putative spouse. ${ }^{5}$ For example, assume that $A$ 's divorce from $B$ is, without $A$ 's knowledge, invalid. If $A$ and $C$, in good faith, enter into a purported marriage, both $A$ and $C$ are putative spouses. That $A$ was incapable of contracting a valid marriage with $C$ is merely a factor considered in determining $A$ 's requisite good faith belief. ${ }^{6}$ The court looks to the facts in the particular case. The education, intelligence, and experience of the one claiming putative status are considered?

Knowledge of the invalidity of the marriage cuts off any rights the person may have gained thereafter as a putative spouse. It does not, however, destroy rights already acquired. Thus, in Lazzarevich $v$. Lazzarevich, ${ }^{8}$ the court treated plaintiff as a putative spouse during the period that she had believed the mar-

1 Both men and women may be either putative or meretricious spouses. Turknette v. Turknette, 100 Cal. App. 2d 271, 223 P.2d 495 (1950). It is often more convenient to refer to the putative or meretricious spouse as "she" because this is the posture in which most of the cases are decided. At times this device will be used in the discussion to follow.

2 Coats v. Coats, 160 Cal. 671, 118 Pac. 441 (1911); Lazzarevich v. Lazzarevich, 88 Cal. App. 2d 708, 200 P.2d 49 (1948); see Note, 37 Calrf. L. Rev. 671 (1949).

3 Sanguinetti v. Sanguinetti, 9 Cal. 2d 95, 69 P.2d 845 (1937); Sancha v. Arnold, 114 Cal. App. 2d 772, 251 P.2d 67 (1952).

4 Sancha v. Arnold, supra note 3.

5 Lazzarevich v. Lazzarevich, 88 Cal. App. 2d 708, 200 P.2d 49 (1948). Although defendant was also a putative spouse, the court permitted recovery by the plaintiff. See also Sanguinetti v. Sanguinetti, 9 Cal. 2d 95, 69 P.2d 845 (1937).

${ }^{6}$ Cf. Vallera v. Vallera, 21 Cal. 2d 681, 134 P.2d 761 (1943) ; Feig v. Bank of Italy Nat'l Trust \& Sav. Ass'n, 218 Cal. 54, 21 P.2d 421 (1933); Oakley v. Oakley, 82 Cal. App. 2d 188, 185 P.2d 848 (1947).

'See, e.g., Flanagan v. Capitol Nat'l Bank, 213 Cal. 664, 3 P.2d 307 (1931) (denying recovery); Santos v. Santos, 32 Cal. App. 2d 62, 89 P.2d 164 (1939) (allowing recovery).

8 \&8 Cal. App. 2d 708, 200 P.2d 49 (1948). 
riage to be valid. No claim as a putative spouse could be made, however, after she discovered the invalidity.

\section{B. Right to Accumulated Property}

\section{Upon Dissolution of the Relationship}

In California a legal wife ordinarily has a statutory right to a share of community property upon dissolution of the marriage contract. ${ }^{9}$ Though a putative spouse has no similar statutory right, the courts do permit recovery of an equitable share of the property accumulated during the relationship. The division of property is made as if the putative spouse were the legal wife of defendant:

[T] he courts of this state, independent of statutory authcrity, in the exercise of their broad equitable powers, have held that, where an unmarried ccuple live together as husband and wife, and where one, at least, honestly and in gocd faith believes he or she is married, he or she is a putative spouse and his or her property rights will be protected. ... In such cases the courts lcok to the statutes dealing with divorces, annulment or separate maintenance not as a source of power, but as furnishing a standard to be used by way of analogy. 10

In effect, then, upon termination of the putative relationship, a putative spouse is entitled to the same share of "putative property"11 as a wife is to community" property. ${ }^{13}$ Thus, if the cause of the dissolution of a putative marriage is other than adultery, incurable insanity or extreme cruelty, the "putative property" will be divided equally between the spouses. But if the marriage is dissolved because of adultery, incurable insanity, or extreme cruelty, the innocent spouse is entitled to more than one half of the "putative property."14

\section{Upon Death of One Spouse}

\section{a. Property Accumulated During Putative Marriage}

Where a putative marriage is terminated by death, the surviving putative

${ }^{9}$ CaL. Crv. Code $\$ 146$ provides in part that "if the decree is rendered on the ground of adultery, incurable insanity or extreme cruelty" then "the community property . . . shall be assigned to the respective parties in such proportions as the court, from all the facts of the case, and the conditions of the parties may deem just." Thus where divorce is procured on one of these three grounds, more than one half of the community property must be awarded to the innocent spouse. Harrold v. Harrold, $43 \mathrm{Cal} .2 \mathrm{~d} 77,217$ P.2d 489 (1954) (p.aintiff awarded $51.13 \%$ of the total estate); Gorman v. Gorman, $134 \mathrm{Cal}$. 378, 66 Pac. 313 (1901).

${ }^{10}$ Turknette v. Turknette, 100 Cal. App. 2d 271, 274, 223 P.2d 495, 498 (1950). See also Ceats v. Coats, 160 Cal. 671, 118 Pac. 441 (1911); Macchi v. La Rocca, 54 Cal. App. 98, 201 Pac. 143 (1921).

11 Nowhere in any case found does the court use the term "putative property." Since there can be no community property in the absence of a valid marriage, however, a substitute term must be found. The term "quasi-community property," previously used to describe such property, can no longer be used because of its adoption in the California statutes. The phrase "putative property" seems to convey the intended meaning. Therefore, for the purposes of this comment tbat property acquired by the putative spouses which would have been characterized as community but for the invalidity of the marriage will be referred to as putative property.

12 Although no cases found have given the putative spouse a share of "quasi-community" property as defined by CAL. CIv. CODE $\S 140.5$, seemingly the putative spouse would also receive the wife's share of such property.

13 Sanguinetti v. Sanguinetti, 9 Cal. 2d 95, 69 P.2d 845 (1937); Schneider v. Schneider, 183 Cal. 335, 191 Pac. 533 (1920).

14 See note 9 supra. 
spouse is not necessarily restricted to a share in the putative property. In Feig v. Bank of America Nat'l Trust $\&$ Sav. Ass' $n{ }^{15}$ the California Supreme Court awarded the surviving putative spouse all of the putative property accumulated during the relationship. The court rejected the contention, based upon cases involving dissolution of putative marriages by legal action, that the surviving spouse was entitled to only one half of such property. The court stated that even though the property was not community in character, it should "be marked by all the incidents of community property."16 Thus, although the deceased spouse could presumably dispose of his half by will, if he dies intestate, as in Feig, the surviving putative spouse is entitled to all of the putative property. ${ }^{17}$ The fradulent concealment of the invalidity of the marriage by the decedent in Feig may have influenced the court, but the same result has been reached in the absence of fraud to the exclusion of children of a former, valid marriage. ${ }^{18} \mathrm{Sim}$ ilarly, as against a former wife of the spouse that dies intestate, the putative spouse is entitled to all of the putative property accumulated during the relationship. 19

\section{b. Separate Property of Deceased Spouse}

A more difficult question is who is entitled to the separate property of a husband survived by both a legal wife and a putative spouse. He may of course devise his separate property as he sees fit. ${ }^{20}$ But if he dies intestate, his "surviving spouse" has a statutory right to a share of his separate property. ${ }^{21}$ In the absence of children of either marriage, one solution would be to award half of the property to the legal wife and the other half to the putative spouse. Such a result would deprive the parents of the husband or their issue of a share in the separate property; ${ }^{22}$ but since the parents would not have taken had there been issue of either marriage, this solution does not seem as harsh as would a denial of the expectation of either the legal wife or the putative spouse.

Where there is issue of either or both of the marriages, the problem becomes more complex. Since issue of a void marriage are legitimate, ${ }^{23}$ the children of a putative marriage should have the same right to share in decedent's separate property as those of a valid marriage. Where two or more children survive, the "surviving spouse" of decedent has a statutory right to one third of his separate property. ${ }^{24}$ The other two thirds is divided equally among the children. Thus it appears that the legitimate children of the putative marriage would share the two thirds with the children of the valid marriage. This would leave one third to be divided equally between the legal wife and the putative spouse. This result would protect the rights of the two spouses as well as those of the children.

155 Cal. 2d 266, 54 P.2d 3 (1936).

16 Id. at 273,54 P.2d at 7.

17 CAL. ProB. CODE $\$ 201$ : "Upon the death of either husband or wife, one-half of the community property belongs to the surviving spouse; the other half is subject to the testamentary disposition of the decedent, and in the absence thereof goes to the surviving spouse. ..."

18 Estate of Krone, 83 Cal. App. 2d 766, 189 P.2d 741 (1948).

19 Mazzenga v. Rosso, 87 Cal. App. 2d 790, 197 P.2d 770 (1948).

20 See Cal. Prob. Code $\$ 20$.

21 This share is determined by CaL. Prob. Code \$§ 221, 223-24.

22 See Car. Prob. Code $§ 223$.

23 Car. Civ. Code $\$ 85$.

24 Cax. Prob. Code § 221. 


\section{Miscellaneous Rights Upon Death: Wrongful Death; Workmen's Compensation; Social Security Benefits; Family Allowance; and Homestead}

Once it was established that a putative spouse had an intestate right it was but a short step to allowing her to maintain a wrongful death action. In Kunakoff v. Woods, ${ }^{25}$ it was held that since a putative spouse inherits as an "heir" of her spouse, she is entitled to maintain an action for his wrongful death. ${ }^{26}$

The right of the putative spouse to recover a workmen's compensation award has long been established. ${ }^{27}$ The test of eligibility is essentially the same as that required for putative status, i.e., a good faith belief that a legal marriage existed. Equating the rights of the putative spouse with those of the legal wife in these cases was easy, for the "good faith belief" test appears in the Workmen's Compensation Act itself. ${ }^{28}$

The right of a California putative spouse to benefits under the Social Security Act is also well settled. ${ }^{29}$ The act provides that an invalidly married claimant is nevertheless entitled to recovery if she occupies the status of a legal wife for the purposes of intestate succession. ${ }^{30}$ Since the California courts have placed

25166 Cal. App. 2d 59, 332 P.2d 773 (1958).

${ }^{26}$ CaL. Code Civ. Proc. $\$ 377$ provides that an action for wrongful death may be maintained by the decedent's "heirs or personal representatives."

27 Temescal Rock Co. v. Industrial Acc. Comm'n, 180 Cal. 637, 182 Pac. 447 (1919); Landsrath v. Industrial Acc. Comm'n, 77 Cal. App. 509, 247 Pac. 227 (1926).

28 CAL. LAB. CODE $\S 3503$. Dependency on the husband for support must also be shown. Although a legal wife hiving with the deceased at his death is conclusively presumed to be wholly dependent, CAL. LAB. CODE $\$ 3501$, the putative spouse is not entitled to such a presumption. Temescal Rock Co. v. Industrial Acc. Comm'n, 180 Cal. 637, 182 Pac. 447 (1919); De Freece v. Industrial Acc. Comm'n, 26 Cal. App. 2d 584, 80 P.2d 129 (1938) (by implication).

29 Aubrey v. Folsom, 151 F. Supp. 836 (N.D. Cal. 1957); Speedling v. Hobby, 132 F. Supp. 833 (N.D. Cal. 1955).

3071 Stat. 519 (1957), as amended, 42 U.S.C. $\S 416$ (h) (1) (A) (Supp. II, 1960). In 1960, para. (B) was added to extend the scope of coverage to imclude some putative spouses who are not entitled to the rights of an heir in other states. The claimant must have in good faith gone through a marriage ceremony which would have been valid but for an unknown legal impediment. The impediment is limited to a defect in the ceremony itself or an invalid divorce. Moreover, if there is a legal wife or another putative spouse wlo is entitled to benefits because she is deemed an heir under state law, the provisions of para. (B) are imoperative.

There remains a question whether both a legal wife and a putative spouse who is deemed an heir under state law are entitled to benefits under the Social Security Act. Prior to 1957, a wife, widow, or putative spouse was entitled to insurance benefits only if she was "living with" the insured at his death or when application was made. It is doubtful, therefore, that there could be more than one eligible claimant. In 1957 the "living with" requirement was climinated and it may now be possible to have both a legal wife or widow and a putative spouse who are eligible for benefits accruing subsequent to 1957. See 71 Stat. 518 (1957), as amended, 42 U.S.C. $\S 402$ (1958); Spier v. Flemming, 186 F. Supp. 614 n.1 (W.D.N.Y. 1960).

Where other federal compensatory statutes lack language specifically including a putative spouse the result has been to deny recovery. See Lawson v. United States, 192 F.2d 479 (2d Cir. 1951), cert. denied, 343 U.S. 904 (1952) (Death on the High Seas Act); Beebe v. Moormack Gulf Lines, Inc., 59 F.2d 319 (5tll Cir. 1932) (Federal Employer's Liabihty Act); Cnitcd States v. Robinson, 40 F.2d 14 (5th Cir. 1930) (War Risk Insurance Act); Keyway Stevedoring Co. v. Clark, 43 F.2d 983 (D. Md. 1930) (Longshoremen's and Harbor Workers' Compensation Act). 
the putative spouse in that position, death benefits under the act are recoverable by her. ${ }^{31}$

The homestead rights of the putative spouse are not so clear. ${ }^{32}$ The fact that the marriage of the declarents is putative may have no effect on the validity of a stautory homestead. A declaration of homestead has been held invalid as against creditors when made by a meretricious spouse. ${ }^{33}$ A subsequent decision held another declaration of homestead invalid, but the opinion does not make clear whether the declarent was a putative or meretricious spouse. ${ }^{34}$

Even if a creditor may reach the purported homestead property of a putative spouse, it does not necessarily follow that the declaration should be ineffective as between the parties to the marriage. No reported California decisions treating this problem have been found. In general, where a legal marriage is dissolved by an action for divorce or separate maintenance, the party awarded the decree may be assigned the statutory homestead. ${ }^{35}$ Since the putative spouse is treated as a legal wife for division of the putative property, arguably a court should have the power to grant her the homestead as well.

A more difficult question is presented by the putative spouse's homestead rights upon the death of the other spouse. Again there are no reported California decisions. If a statutory homestead has previously been selected, it must be set apart for the benefit of the "surviving spouse." ${ }^{36}$ If the marriage's putative nature will not destroy the validity of a homestead already declared, a putative spouse should be entitled to the statutory homestead. If none was declared, or the putative spouse is not so entitled, she may nevertheless be able to secure a probate homestead. ${ }^{37}$ Where no statutory homestead has been selected, the court must set aside a homestead for the "surviving spouse." 38 This probate homestead is free from the claims of creditors and superior to the rights of other heirs, devisees, and legatees. Again, there is no authority on the propriety of extending this homestead right to a putative spouse. The difficulty with such an extension is that the California courts have equated the right to a probate homestead to the right to receive a family allowance. ${ }^{39}$ And the right of a putative spouse to a family allowance is questionable as will appear below.

31 Although it has not been decided whether the putative spouse may inherit the other spouse's separate property, see text accompanying notes 19-24 supra, the presence of scparate property will not preclude recovery under the Social Security Act. Aubrey v. Folson, 151 F. Supp. 836 (N.D. Cal. 1957).

32 As to homesteads generally see Comment (pts. 1-2), 26 CALIF. L. REv. 241, 466 (1938).

33 Rich v. Ervin, 86 Cal. App. 2d 386, 194 P.2d 809 (1948).

34 Shumaker v. Biscailuz, 130 Cal. App. 2d 414, 278 P.2d 939 (1955). It can be argued that the spouses were meretricious, since the court in Shumaker rested its decision on Rich $\mathrm{v}$. Ervin, supra note 33, and stated that the latter held a declaration invalid when it contained a statement "that the declarant knew to be false," i.e., that the claimant was married. $130 \mathrm{Cal}$. App. 2d at 415, 278 P.2d at 940.

35 CaL. CIv. CODE $\$ 146$. In general, if the homestead was selected from community property, it may be awarded absolutely. If selected from the separate property of either, it may be assigned to the former owner, subject to the power of the court to assign it to the successful party for a himited period.

36 Cal. Prob. Code $\$ 661$.

${ }^{3 i}$ A surviving spouse's putative status should not in any event effect the rights of minor children to a probate homestead. CAL. PrOB. CODE $\$ 661$ provides that if there is no "surviving spouse," a probate homestead must nevertheless be set aside for the minor children of the decedent.

38 Cal. Prob. Code $\S 661$.

39 Estate of Brooks, 28 Cal. 2d 748, 171 P.2d 724 (1946), 35 Calif. L. Rev. 303 (1947); cf. Estate of Myers, 115 Cal. App. 443, 1 P.2d 1013 (1931). 
The family allowance is intended to protect the family of the deceased during the administration of the estate. The "widow" and children are entitled to a reasonable amount out of the estate as is necessary for their support. ${ }^{40}$ The Supreme Court of California has held that the test of eligibility for a family allowance is whether the surviving spouse has a right to support at decedent's death. ${ }^{41}$ It seems to be settled although questionable law that a putative spouse is not entitled to support from her spouse. ${ }^{42}$ Thus the courts may have indirectly foreclosed the family allowance award to the putative spouse. There is only one decision that has touched upon the question directly. In Estate of Cooper, ${ }^{43}$ the trial court had awarded a family allowance to the spouse of decedent's last "marriage." On appeal it was held that decedent and his former wife were never divorced. Hence, the decision rendered his last spouse putative. The judgment awarding her a family allowance and denying such allowance to his legal wife was reversed, thus denying the putative spouse the family allowance. In light of the purpose of the family allowance provisions, such a result should be avoided. In the usual case the putative spouse is in fact dependent upon decedent for support. The family allowance is intended as support to decedent's dependent family until administration is completed. To thwart this purpose because the California courts have not yet allowed the putative spouse a right to support seems unnecessary.

\section{Right to Compensation for Services: A Substitute for Alimony?}

That a putative spouse is not entitled to alimony is a familiar rule to the California lawyer. ${ }^{44}$ A putative spouse can, however, recover the reasonable value of services rendered the other spouse less the value of support and maintenance furnished her. ${ }^{45}$ Early decisions permitted such recovery on the theory that failure to do so would result in giving the spouse who caused the deception the benefit of his fraudulent representation that the marriage was valid. Thus, in Mixer v. Mixer, ${ }^{46}$ the court affirmed a decision allowing defendant's cross complaint for the reasonable value of services rendered during the putative marriage. Plaintiff had drugged defendant while they were traveling to Nevada to be remarried. When defendant awoke, plaintiff convinced her that a marriage ceremony had been performed. Under this fact situation, the court had no difficulty finding intentional fraud. It is clear, however, that recovery for services rendered is not limited to cases where intentional fraud is present. In Sanguinetti $v$. Sanguinetti, ${ }^{47}$ plaintiff's former marriage was still in effect when she married defendant. Nevertheless, since both plaintiff and defendant believed that there existed a valid marriage between them there could be no finding of intentional

40 Cal. Prob. Code $\S 680$. See Estate of Blair, 42 Cal. 2d 728, 269 P.2d 612 (1954); 4 Witkin, Summary of Caltfornia Law 3293 (1960).

41 Estate of Brooks, supra note 39.

42 Although the rule is of doubtful soundness, a putative spouse is not entitled to permanent alimony in California. See note 44 and text accompanying notes 44-52 infra.

4397 Cal. App. 2d 186, 217 P.2d 499 (1950).

44 E.g., Sanguinetti v. Sanguinetti, 9 Cal. 2d 95, 69 P.2d 845 (1937); Millar v. Millar, 175 Cal. 797, 167 Pac. 394 (1917).

45 Sanguinctti v. Sanguinetti, 9 Cal. 2d 95, 69 P.2d 845 (1937); Lazzarevich v. Lazzarevich, 88 Cal. App. 2d 708, 200 P.2d 49 (1948); Marsh v .Marsh, 79 Cal. App. 560, 250 Pac. 411 (1926); Mixer v. Mixer, 2 Cal. App. 227, 83 Pac. 273 (1905).

462 Cal. App. 227, 83 Pac. 273 (1905).

479 Cal. 2d 95, 69 P.2d 845 (1937). 
fraud. The supreme court held that where the "de facto husband committed acts of cruelty which if the marriage had been valid would constitute cause for divorce," his putative spouse is "entitled to be paid in so far as her services exceeded in value the support provided by her supposed husband." 48

It can be seen that the supreme court in Sanguinetti extended the Mixer result to the dissolution of a putative marriage where, although there is no fraud, there are acts of cruelty on the part of the putative husband. The appellate court in Lazzarevich v. Lazzarevich ${ }^{49}$ took note of this extension and, in the absence of proof of either intentional fraud or cruelty, allowed the putative spouse to recover the reasonable value of her services less expenditures. No court of appellate jurdisdiction has yet awarded a putative spouse found to have committed acts of adultery or cruelty the reasonable value of services rendered. These recent decisions, however, may indicate that even in such a case recovery would be permitted.

It is obvious that this compensatory device affords a convenient way around the rule that a putative spouse is not entitled to alimony.50 Yet this form of relief is unsatisfactory. The claimant may be seeking relief based upon the rendition of household services. Placing a monetary value on such services is a difficult task. Similarly, the amount of expenditures made by the defending spouse for the support and maintenance of the claimant is somewhat speculative. Even if the cost of food, lodging, and clothing can be ascertained with reasonable accuracy, the court can only guess at the total cost of many incidental expenditures. All of this may be complicated by conflicting and probably uncorroborated testimony. With both the value of services rendered and the amount of expenditures for maintenance and support speculative, the award in any particular case may well depend on the length of the proverbial "Chancellor's foot."

There is another and perhaps more fundamental objection to this compensatory device as a final solution. The increasing liberality of the courts in awarding the reasonable value of services may place a premium on the claimant being a putative spouse rather than a legal wife. A legal wife is entitled to permanent alimony only where she possesses grounds for divorce. ${ }^{51}$ The putative spouse, on the other hand, if Lazaarevich is right, is entitled to the reasonable value of services even where the defendant has not committed acts that would be grounds

48 Id. at 101,69 P.2d at 848 .

$4988 \mathrm{Cal}$. App. 2d 708, 200 P.2d 49 (1948). It should be noted, however, that where intentional fraud is present, later cases still base recovery on this theory. See, e.g., Marsh v. Marsh, 79 Cal. App. 560, 250 Pac. 411 (1926). See Restatement, Restitution $\$ 40$, comment $b$ (1937), cited in Lazzarevich v. Lazzarevich, 88 Cal. App. 2d 708, 715, 200 P.2d 49, 54 (1948).

${ }^{50}$ See cases cited note 44 supra; Note, 37 CaxIf. L. Rev. 671, 679 (1949). Where the status of the spouse as putative is undisputed, this rule would seem to apply to both permanent and temporary alimony. The question of status normally arises, however, when one spouse sues her alleged husband for divorce, and the latter defends on the ground that their marriage is invalid. In such a case the plaintiff should be entitled to temporary alimony, costs, and counsel fees until the validity of the marriage, and hence the plaintiff's status, is judicially determined. Cf. Hudson v. Hudson, 52 Cal. 2d 735, 344 P.2d 295 (1959); Dunphy v. Dunphy, 161 Cal. 87, 118 Pac. 445 (1911).

51 See, e.g., Ex parte Spencer, 83 Cal. 460, 464, 23 Pac. 395, 396 (1890) (one sceking permanent ahimony must have been wronged); Salvato v. Salvato, 195 Cal. App. 2d 869, 16 Cal. Rptr. 263 (1961) (wife awarded alimony based on extreme cruclty where only husband sought divorce), 50 Calif. L. Rev. 353 (1962). See generally 1 Armsstronc, California FAMIIX LAW 349-54 (1953). 
for divorce were the marriage valid. ${ }^{52}$ There is no justification for giving a putative spouse greater rights upon the dissolution of the putative relationship than has the legal wife upon the dissolution of her marriage.

\section{E. Evaluation of the Putative Spouse's Right to Compensation- A Proposed Solution}

Although no reported California decision has awarded claimant a substantial share of property and, at the same time, the reasonable value of her services, the extent to which one form of relief bars the other is unclear. Professor Armstrong ascribes to the view that these remedies are mutually exclusive. ${ }^{53}$ Nevertheless, if an award of reasonable value of services is merely a device to circumvent the rule precluding alimony, logic dictates that both remedies be available to the putative spouse.

As we have seen, the California courts have progressively equated the rights of the putative spouse to those of the legal wife. She is entitled to share in the putative property upon death ${ }^{54}$ or divorce; ${ }^{55}$ she is entitled to recover a workmen's compensation award ${ }^{58}$ and to bring an action for wrongful death. ${ }^{57}$ She has, however, no right to permanent alimony. And, since a putative spouse is said not to be entitled to a right to support, she is probably not entitled to either a family allowance or a probate homestead. One basis upon which alimony is awarded a legal wife is that the offending husband has deprived her of support.58 Certainly a putative spouse is no less deprived of a future expectation than is a legal wife. Although she should not be given greater rights than has the legal wife merely because she is putative, it seems inconsistent to deny the putative spouse the right to alimony, family allowance, and probate homestead.

II

\section{MERETRICIOUS SPOUSE}

\section{A. Who Is a Meretricious Spouse}

One who cohabits $^{59}$ with another knowing that the relationship does not constitute a valid marriage is a meretricious spouse. ${ }^{60}$ Either spouse, or both, may be meretricious. Thus, if a prior marriage of either is still valid, and both know

52 Lazzarevich v. Lazzarevich, 88 Cal. App. 2d 708, 200 P.2d 49 (1948).

63 See 1 Armstrong, California Family Law 862 (1953).

54 See text accompanying note 15 supra.

65 See text accompanying note 13 supra.

60 See text accompanying note 28 supra.

5i See text accompanying note 26 supra.

58 Ex parte Spencer, 83 Cal. 460, 23 Pac. 395 (1890).

68 Cohabitation scems to contemplate more than a single night of intimacy. Although no minimum period of time necessary is evident from any of the cases reviewed, the term cohabitation seems to contemplate a situation where the parties have "set up house keeping." Sce, e.g., Keene v. Keene, 57 Cal. 2d 657, 371 P.2d 329, 21 Cal. Rptr. 593 (1962) (eighteen years); Vallera v. Vallera, 21 Cal. 2d 681, 134 P.2d 761 (1943) (three years); Flanagan v. Capital Nat'l Bank, 213 Cal. 664, 3 P.2d 307 (1931) (eighteen years).

60 Where a valid marriage does in fact exist but the parties mistakenly behicve the marriage invalid, there is no apparent reason why the spouses should be denied the statutory rights accorded legal spouses. The lack of belief in the validity of the marriage is important only because it is in equity that a putative spouse must seek relief. Parties legally married in fact, on the other hand, have their rights determined by law. 
this, both are meretricious spouses. ${ }^{61}$ If only one is aware of the invalidity of the present marriage, that party is a meretricious spouse. The "innocent" party is not tainted by the knowledge of his or her partner. ${ }^{62}$ Nor is it significant that one or even both of the parties is capable of contracting a valid marriage. ${ }^{63} \mathrm{It}$ is the knowledge of invalidity, not the capability of the parties to contract a valid marriage, that makes a relationship meretricious.

\section{B. Right to Property in the Absence of an Agreement}

Although a putative spouse is entitled to a share of property accumulated during the putative marriage, the meretricious spouse is not entitled to share in the absence of an express agreement to that effect. ${ }^{64}$ Cohabitation alone does not give an interest in property accumulated.65 The court leaves the parties in the position in which they have placed themselves. ${ }^{60}$ In doing so, it intentionally denies that any reasonable expectations deserving equitable consideration can exist where no agreement to share is present. ${ }^{67}$ The only apparent exception is where there has been an actual contribution of funds or property of value.

\section{Resulting Trust as a Remedy}

The remedy available to a meretricious spouse who has provided all or a portion of the purchase price to acquire property placed in the name of the other spouse is a resulting trust. ${ }^{68}$ The contribution must have been of funds or other property of value. ${ }^{69}$ In such a case, the meretricious spouse is entitled to a share of the property proportionate to his contribution..$^{70}$ For example, assume that $B$, a meretricious husband, acquires property and places the title in his name. If his meretricious spouse $A$ contributed half of the purchase price, a court of equity would decree that $B$ holds a one half interest in the property as trustee for $A .^{71}$

Seemingly, the contribution need not be of separately identifiable property or money. If the meretricious spouses work together in a common enterprise, and and if there is an agreement to that effect, the proceeds of their joint labor will become the joint property of both. If these proceeds are used to purchase prop-

61 See Keene v. Keene, 57 Cal. 2d 657, 371 P.2d 329, 21 Cal. Rptr. 593 (1962).

62 See Lazzarevich v. Lazzarevich, 88 Cal. App. 2d 708, 200 P.2d 49 (1948).

63 In Keene v. Keene, supra note 61, the plaintiff was legally capable of marriage. The court denied her relief because, under the circumstances there present, only a putative spouse could bave recovered and clammant did not qualify as a putative spouse. Her lack of belief in the validity of the marriage-not her legal ability to contract a valid marriage-determined her status.

64 Keene v. Keene, 57 Cal. 2d 657, 662, 371 P.2d 329, 332, 21 Cal. Rptr. 593, 596 (1962); Vallera v. Vallera, 21 Cal.2d 681, 684-85, 134 P.2d 761, 763 (1943).

6.; Flanagan v. Capital Nat'l Bank, 213 Cal. 664, 3 P.2d 307 (1931).

66 Oakley v. Oakley, 82 Cal. App. 2d 188, 185 P.2d 848 (1947).

6i Vallera v. Vallera, 2I Cal. 2d 681, 685, 134 P.2d 761, 762-63 (1943); Baskett v. Crook, 86 Cal. App. 2d 355, 195 P.2d 39 (1948).

68 Hayworth v. Williams, 102 Tex. 308, 116 S.W. 43 (1909), cited in Vallera v. Vallera, 21 Cal. 2d 681, 685, 134 P.2d 761, 763 (1943).

69 Vallera v. Vallera, 21 Cal. 2d 681, 134 P.2d 761 (1943).

70 Cf. Goes v. Perry, 18 Cal. 2d 373, 115 P.2d 441 (1941); Watson v. Poore, 18 Cal. 2d 302, 115 P.2d 478 (1941) (fractional interest) ; Padilla v. Padilla, 38 Cal. App. 2d 319, 100 P.2d 1093

(1940) (same principles applied where claimant was meretricious spouse).

71 See cases cited note 70 supra. 
erty, "each would own the property acquired in proportion to the value of his labor contributed to the acquisition of it." 22

The basic requirement for imposition of a resulting trust is that the spouse seeking its imposition must have contributed consideration either before or at the time of purchase. Later contributions or improvements are not enough. ${ }^{73}$ Nor is a resulting trust available to a meretricious spouse whose only claim to an interest in property is that services were performed that increased its value. Thus, in Keene v. Keene, ${ }^{74}$ plaintiff, a meretricious spouse, had lived with defendant for eighteen years. Although she contributed neither money nor property of value when the property was acquired, she did work on the defendant's ranch and ran his household. ${ }^{75}$ When the farm was sold, defendant used the proceeds to purchase a furniture business. Again, plaintiff did not give financial assistance. The Supreme Court of California held that a resulting trust was not established in the ranch because legal title was in the defendant before the inception of the meretricious relationship. Moreover, it was held that no trust could be imposed on the furniture business. The only consideration the claimant could point to as contributed by her in the acquisition of the business was a purported imcrease in the value of the ranch due to her services. The court stated that "the labor of a farm hand ... also 'increases the value' of the ranch ... where he works; yet it is manifest that he thereby acquires no interest in the property itself or in the proceeds of its sale ..." ${ }^{76}$ Although the analogy is questionable, ${ }^{77}$ the court has thus made it clear that such an indirect contribution by the meretricious spouse is not enough.

\section{Constructive Trust as a Remedy}

If a meretricious spouse is induced to transfer title to property held in his own name to the other spouse, a constructive trust may be an available remedy. In Keene, the court in a footnote dismissed the possibility that the claimant could seek the imposition of a constructive trust upon property held in the name of her meretricious spouse. ${ }^{78}$ This was because she had not given "property" to the defendant. She had contributed mere services, and a constructive trust will not be imposed for the value of services rendered.

72 Hayworth v. Williams, 102 Tex. 308, 314, 116 S.W. 43, 46 (1909), relied on by the court in Vallera v. Vallera, 21 Cal.2d 681, 134 P.2d 761 (1943). The inability of the claimant to establish the amount contributed may, however, result in a refusal by the court to impose a resulting trust. Keene v. Keene, 57 Cal. 2d 657, 665, 371 P.2d 329, 334, 21 Cal. Rptr. 593, 598 (1962).

73 E.g., Eliott v. Wood, 95 Cal. App. 2d 314, 318, 212 P.2d 906, 909 (1949); McGuin v. Rice, 88 Cal. App. 2d 914, 917-18, 199 P.2d 742, 744 (1948).

7457 Cal. 2d 657, 371 P.2d 329, 21 Cal. Rptr. 593 (1962).

75 The court found that plaintiff had not only performed the "usual and customary work of a housewvife," but had also performed "work and labor for the mutual benefit of defendant and plaintiff on a certain ranch," i.e., raising turkeys, chickens, sheep, cattle, clearing land, sowing, raising and harvesting crops. Id. at 663 n.3, 371 P.2d at 332 n.3, 21 Cal. Rptr. at 596 n.3.

76 57 Cal. 2d at 668, 371 P.2d at 335-36, 21 Cal. Rptr. at 599-600.

77 It would seem that in all but the extraordinary case such an employee would be salaried and have no expectation of acquiring an interest in the business property by reason of his services. A meretricious spouse, on the other hand, ordinarily receives no "salary" other than support and maintenance and may reasonably expect to be compensated for services that increase the value of the other spouse's property.

7857 Cal. 2 d at 665 n.5, 371 P.2d at 333 n.5, 21 Cal. Rptr. at 597 n.5. 
In addition to this transfer of property requirement, the meretricious spouse must prove that it was induced by actual or constructive fraud. Where actual fraud is shown, a trust will be imposed even though the parties were dealing at "arm's length." 79 Where no actual fraud can be proven, constructive fraud ${ }^{80}$ is sufficient to support the imposition of a trust. ${ }^{81}$ But if constructive fraud is relied upon, a confidential relationship must be shown to have existed between the title holder and the person seeking to impose the trust. ${ }^{82}$

In Patterson v. Davis, ${ }^{83}$ plaintiff, a woman who had cohabited with decedent for nine years, sought to have the court set aside a quitclaim deed executed by her. Her claim was that decedent had taken advantage of a confidential relationship. The court stated that a meretricious relationship alone does not give rise to a confidential relationship. ${ }^{84}$ There must be a showing that a relationship of trust did exist in fact, and that the relationship was used to obtain unfair advantage by a breach of this trust. Although inconclusive in itself, the meretricious situation in no way bars establishment of a relationship of confidence. ${ }^{85}$ Although the fact that a meretricious relationship exists is evidence that an attitude of love exists between the parties, ${ }^{86}$ the particular facts in each case govern. ${ }^{87}$ If the meretricious spouse is successful in establishing that a confidential relationship with her partner existed, it will become the fiduciary's task to prove that he acted faithfully. ${ }^{88}$

\section{Equitable Lien as a Remedy}

Where a constructive trust is not available to the meretricious spouse because of the absence of both fraud and a confidential relationship, an equitable lien may be available for relief. Both the constructive trust and the equitable lien are imposed to prevent unjust enrichment. But while the former gives plaintiff equitable ownership of the property and transforms the legal owner into a trus-

79 See, e.g., Fulton v. Jansen, 99 Cal. 587, 34 Pac. 331 (1893) (dictum) ; Nordholt v. Nordholt, 87 Cal. 552, 26 Pac. 599 (1891); Brison v. Brison, 75 Cal. 525, 17 Pac. 689 (1888).

80 Constructive fraud implies the breach of a fiduciary duty. No intention to violate the duty is necessary. E.g., Estate of Arbuckle, 98 Cal. App. 2d 562, 568-69, 220 P.2d 950, 954-55 (1950).

81 Id. at 568,220 P.2d at 954 .

82 See, e.g., Stobie v. Stobie, 116 Cal. App. 2d 360, 253 P.2d 765 (1953).

83121 Cal. App. 2d 152, 262 P.2d 601 (1953).

84 See also McDougall v. MIcDougall, 135 Cal. 316, 67 Pac. 778 (1902); Donze v. Donze, 88 Cal. App. 769, 264 Pac. 294 (1928). But see Holmes v. Holmes, 98 Cal. App. 2d 536, 220 P.2d $603(1950)$, for an indication that a meretricious relationship is enough in itself to create a confidential relationship.

85 See Gjurich v. Feig, 164 Cal. 429, 129 Pac. 464 (1913) ; Mack v. White, 97 Cal. App. $2 d$ 497, 218 P.2d 76 (1950).

86 Gatje v. Armstrong. 145 Cal. 370, 372-73, 78 Pac. 872, 873 (1904). In discussing the conficlential relationship between plaintiff and defendant, both of whom were meretricious spouses, the court said: "Conceding that there was no false representation as to a suit having been threatened by plaintifi's divorced husband, the relations of the parties were of such a character that it was natural isr plaintiff to repose, as she did, the highest trust and confidence in defendant."

87 The court will consider the disparity of age, intelligence, and physical health of the party seeking the trust and the party on whom the imposition is sought. See, e.g., Gjurich v. Feig, 164 Cal. 429, 129 Pac. 464 (1913) (plaintiff was elderly and infirm); Gatje v. Armstrong, $145 \mathrm{Cal}$. 370, $78 \mathrm{Pac} .872$ (1904) (comparative intelligence an important factor).

88 Cox v. Schnerr, 172 Cal. 371, 156 Pac. 509 (1916). 
tee, the latter merely imposes a lien upon the property. ${ }^{89}$ Title and ownership are retained by the holder of legal title, while the property is charged as security for the outstanding debt.

There is no need to find a confidential relationship when imposing an equitable lien. Although fraud may exist, it also is unnecessary. An equitable lien is, however, only a device employed to secure a recovery where a right to relief is established. Thus in Keene, this remedy was apparently not available to the meretricious claimant because she had contributed mere services, a contribution not compensable in the absence of an agreement. Where an agreement to share the property accumulated or to compensate for services rendered is shown to exist, the remedy of an equitable lien is available. ${ }^{90}$

\section{Right to Property Accumulated and Compensation for Services: Express Agreement Necessary}

In the absence of an agreement, a meretricious spouse is not entitled to the reasonable value of services rendered the other spouse or to a share of the accumulated property. ${ }^{91}$ The mere fact that a meretricious relationship exists has been held a sufficient basis for denying recovery. The decision in Lazzarevich v. Lazzarevich $^{92}$ is a striking example of the refusal of the courts to compensate for services. In Lazzarevich, plaintiff and defendant lived together in a seemingly valid marriage. Unknown to either, the final decree had been entered in a prior divorce action between them. Upon discovering the invalidity of his present marriage, defendant did not inform plaintiff immediately, but when he later did so, plaintiff continued to render further services. The court permitted recovery for services rendered while plaintiff had a good faith belief in the validity of the marriage (the putative period), but denied recovery for the reasonable value of services rendered while she knew of its invalidity (the meretricious period). The court thus made clear the disparity in treatment between the putative and meretricious spouses where there is no agreement for compensation.

Where the meretricious spouses have made an express agreement to pool earnings and slare in the accumulations or to compensate for services, it will be enforced ${ }^{93}$ unless it contemplates compensation for prostitution and is, therefore, void as against public policy. ${ }^{94}$ In order to avoid this stigma, a meretricious spouse seeking to enforce a property or compensation agreement made during or before an illicit cohabitation must show that the consideration for the promise to share or compensate was not the illicit cohabitation, but something of value (household services, for example) given by plaintiff to defendant.

The importance of this requirement is demonstrated by Hill v. Estate of Westbrook. ${ }^{95}$ In Hill, a meretricious spouse filed a claim against the estate of

89 See, e.g., Garcia v. Venegas, 106 Cal. App. 2d 364, 235 P.2d 89 (1951); Sanguinetti v. Sanguinetti, 9 Cal. 2d 95, 69 P.2d 845 (1935). See generally 31 CaL. JUR. 2d Liens $\$ 10$ (1956). ${ }^{90}$ Garcia v. Venegas, 106 Cal. App. 2d 364, 235 P.2d 89 (1951).

91 Keene v. Keene, 57 Cal. 2d 657, 371 P.2d 329, 21 Cal. Rptr. 593 (1962); Vallera v. Vallera, 21 Cal. 2d 681, 134 P.2d 761 (1943).

9288 Cal. App. 2d 708, 200 P.2d 49 (1948).

93 Vallera v. Vallera, 21 Cal. 2d 681, 685, 134 P.2d 761, 763 (1943); Bridges v. Bridges, 125 Cal. App. 2d 359, 270 P.2d 69 (1954).

94 See generally 12 CaL. JuR. 2d Contracts $\$$ 77-78 (1953).

9595 Cal. App. 2d 599, 213 P.2d 727 (1950). 
the decedent for the value of her services rendered and money paid to him. She had assisted decedent for many years in the operation of a rooming house. Sometime after the commencement of her duties, a meretricious relationship had begun. Upon his death, plaintiff discovered that the decedent had not provided for her by will as promised, and brought suit on an oral agreement to compensate her for services. Included in the list of services for which compensation was sought was the "service" of living with the decedent as his wife and bearing him two children. The court held that this inclusion was fatal to the complaint, for concubinage and child bearing are not services for which compensation will be ordered. It seems probable, however, that had there been a valuation stated separately for each service listed in the complaint, the mere inclusion of this illegitimate service would not have precluded recovery for the legitimate services listed.98

It can thus be seen that a meretricious spouse, to be successful in a suit against her former partner, must be able to show the existence of an agreement between them. The opinion in $\mathrm{Hill}^{97}$ seemed to indicate that the courts may be inclined to take a liberal attitude in determining the existence of an agreement. The court in Keene, however, stated that in a meretricious union there is an implication that "any services performed by one party ... without an express agreement for compensation or for sharing in the joint accumulations, are intended by the one performing them as gifts or as his or her contribution to the general living expenses of both." ${ }^{\prime \prime 8}$ Ordinarily, where services of value are rendered another, there is a presumption that compensation was contemplated. ${ }^{99}$ In the absence of an agreement as to the amount of compensation, the court will determine the reasonable value of the services and use this evaluation as a measure of recovery. Not only does this presumption not arise where a meretricious relationship coexists with the rendition of services, but Keene makes it clear that the meretricious spouse will not be able to point to services rendered as any evidence of an agreement between the parties. This would seem to be so whether the services rendered were in the home or in actively assisting in the conduct of the other party's business, as in Keene. Thus, where the meretricious spouse has contributed services only and cannot prove an express agreement to share or compensate, there is no right to recovery. It matters little whether the court bases its refusal on the nonexistence of equitable considerations arising out of the meretricious relationship, as in Vallera $v$. Vallera, ${ }^{100}$ or upon the inference that the services were intended as gifts or as a contribution to defray living expenses, as in Keene.

${ }^{98}$ Since there was no separate evaluation, the court was unable to separate the illegitimate "services" from those services that normally would be a valid subject for compensation. In reaching the conclusion that the complaint inust fail, the court emphasized the lack of information as to the value of the services other than concubinage rendered by plaintiff. Id. at 603 , 213 P.2d at 730.

97 95 Cal. App. 2d 599, 213 P.2d 727 (1950).

9857 Cal. 2d at 668, 371 P.2d at 336, 21 Cal. Rptr. at 600.

99 See, e.g., Gjurich v. Feig, 164 Cal. 429, 431, 129 Pac. 464, 465 (1913).

10021 Cal. 2d 681, 134 P.2d 761 (1943). 


\section{CONCLUSION}

It is evident that the rights of the putative spouse far exceed those of the meretricious spouse. The latter can recover the reasonable value of services rendered or a share of property accumulated during the relationship only if there exists an express agreement to that effect. The putative spouse, on the other hand, has been equated to a legal spouse for many purposes. The major exception is the denial of her right to alimony, a denial which seems logically inconsistent with the present attitude of the California courts. The putative spouse should be entitled to an alimony award in those cases where a legal wife would be so entitled. If the courts prove unwilling to grant this right by an exercise of inherent equity powers, ${ }^{101}$ it should be provided by legislation, thus placing the putative spouse and legal wife on equal footing.

Stanley A. Coolidge, Jr. provided for by statute ...." 